Polish Journal of Microbiology

2011, Vol. 60, No 2, 139-144

ORGINAL PAPER

\title{
Utilization of UF-Permeate for Production of $\beta$-galactosidase by Lactic Acid Bacteria
}

\author{
H.A. MURAD ${ }^{1 *}$, R.I. REFAEA ${ }^{2}$ and E.M. ALY $^{3}$ \\ ${ }^{1}$ Dairy Science Department, National Research Centre, Cairo, Egypt \\ ${ }^{2}$ Microbiology Department, Faculty of Agriculture, Cairo University \\ ${ }^{3}$ Environmental Compliance Office, Federation of Egyptian Industries, Cairo, Egypt
}

Received 7 April 2010, revised 20 December 2010, accepted 15 January 2011

Abstract

Four lactobacilli strains (Lactobacillus bulgaricus, Lactobacillus acidophilus, Lactobacilus casei and Lactobacillus reuteri) were grown in MRS broth and three lactococci strains (Streptococcus thermophilus, Lactococcus lactis subsp. Lactis and Lactococcus lactis subsp. lactis biovar. diacetilactis) were grown in M17 broth. L. reuteri and S. thermophilus were chosen on the basis of the best mean $\beta$-galactosidase activity of 10.44 and $10.01 \mathrm{U} / \mathrm{ml}$ respectively, for further studies on permeate-based medium. The maximum production of $\beta$-galactosidase by $L$. reuteri was achieved at lactose concentration of $6 \%$, initial $\mathrm{pH}$ 5.0-7.5, ammonium phosphate as nitrogen source at a concentration of $0.66 \mathrm{~g} / \mathrm{L}$ and incubation temperature at $30^{\circ} \mathrm{C} / 24 \mathrm{hrs}$ to give $6.31 \mathrm{U} / \mathrm{ml}$. While in case of $S$. thermophilus, maximum $\beta$-galactosidase production was achieved at $10 \%$ lactose concentration of permeate medium, supplemented with phosphate buffer ratio of $0.5: 0.5\left(\mathrm{KH}_{2} \mathrm{PO}_{4}: \mathrm{K}_{2} \mathrm{HPO}_{4}, \mathrm{~g} / \mathrm{L}\right)$, at initial pH 6.0-6.5, ammonium phosphate $(0.66 \mathrm{~g} \mathrm{~N} / \mathrm{L})$ as nitrogen source and incubation temperature $35^{\circ} \mathrm{C}$ for $24 \mathrm{hrs}$ to give $7.85 \mathrm{U} / \mathrm{ml}$.

Key words: L. reuteri, S. thermophilus, $\beta$-galactosidase, lactic acid bacteria (LAB), permeate

\section{Introduction}

The disposal of whey remains a significant problem for the dairy industry. As whey contains 5 to $6 \%$ dissolved solids, including 3 to $5 \%$ lactose, the biological oxygen demand (BOD) is high. Generally, whey must be treated prior to discharge into the environment (Marwaha and Kennedy, 1988).

A number of applications for whey-permeate have been developed in an effort to overcome the problem of its disposal. One alternative is the use of whey as the basic medium for various fermentation processes including the production of ethanol, methane, yeast protein, xanthan gum (Fu and Tseng, 1990) or organic acids such as lactate, propionate or acetate (Mawson, 1994; Huang and Yang, 1998). Another application with a high technological and dietetic interest is the enzymatic hydrolysis of lactose, whose economic importance has been increasing ever since the 1960s (Novalin et al., 2005).

The enzyme $\beta$-D-galactoside galactohydrolase ( $\beta$-galactosidase, E.C. 3.2.1.23, trivially lactase) hydrolyzes lactose, the milk sugar, into two moieties glucose and galactose (Rings et al., 1994). This technically and economically feasible process would also open new possibilities for the utilization of whey and whey-permeate (Zadow, 1993).
While $\beta$-galactosidase has been found in numerous biological systems, microorganisms such as yeasts, molds and bacteria still remain the only commercially exploited sources (Agrawal and Dutta, 1989). More recently, thermophilic bacteria have become an object of interest for the commercial production of $\beta$-galactosidase (Petzelbauer et al., 1999). Among these, special attention has been paid to lactic acid bacteria (LAB) because of their GRAS status (Stiles and Holzapfel, 1997). Lactic acid bacteria have a long tradition of use in the food industry. Their potential uses as a source of enzymes, especially $\beta$-galactosidase, has been shown to be promising (Murad, 1998).

The aim of the current work was to optimize the growth conditions to maximize the production of $\beta$-galactosidase by some LAB strains grown on the newly modified permeate-based medium.

\section{Experimental}

Materials and Methods

Organisms. Seven LAB strains were obtained from the Department of Dairy Microbiology, National Research Centre. The obtained strains were Lactobacillus reuteri, Lactobacillus acidophilus, Lactococcus lactis

\footnotetext{
* Corresponding author: H.A. Murad; P.O.B 12622, Dokki, Cairo, Egypt.; phone: 202 33068626; fax: 202 33370931; e-mail: murad951@ hotmail.com
} 
subsp., lactis biovar diacetilactis, Lactobacillus bulgaricus (241), Streptococcus thermophilus, Lactococcus lactis subsp. lactis and Lactobacillus casei. The obtained strains were maintained and activated in sterile litmus milk, stored in a refrigerator at $4^{\circ} \mathrm{C}$ and tested for their ability to produce $\beta$-galactosidase.

\section{$\beta$-Galactosidase production media and growth conditions}

Synthetic media. Production of $\beta$-galactosidase by lactococci and lactobacilli cultures was examined in M17 synthetic broth medium (Difco) and MRS synthetic broth medium, respectively. The media were inoculated with freshly activated $1 \%$ inoculum and incubated at $37^{\circ} \mathrm{C}$ for $24 \mathrm{hrs}$ according to Vasiljevic and Jelen (2001) and Herreros et al. (2003).

Permeate-based medium. The milk permeate, which is considered as a waste during the production of cheese by ultrafiltration, was obtained from a cheese production factory located in Mansoura City (Nile Delta) and used for the preparation of the permeatebased medium. In the following tests, permeate-based medium components and environmental conditions were investigated for optimum conditions leading to maximize $\beta$-galactosidase production as mentioned by Murad (1998).The $\mathrm{pH}$ of permeate-based media in the experiments was adjusted to 6.5 by $1 \mathrm{~N} \mathrm{NaOH}$ or $1 \mathrm{~N} \mathrm{HCl}$ and then sterilized for 30 minutes at $110^{\circ} \mathrm{C}$. The media were inoculated with $1 \%$ inoculum of the freshly activated strains ( $24 \mathrm{hrs})$ and then incubated at for $24 \mathrm{hrs} 37^{\circ} \mathrm{C}$.

\section{Effect of media composition and environmental} conditions on the production of $\boldsymbol{\beta}$-galactosidase

The previously mentioned permeate-based medium was employed for improvement of $\beta$-galactosidase production by varying its components qualitatively and quantitatively under variable environmental conditions as follows:

Effect of lactose concentration. Different concentrations of lactose in permeate medium $(2,4,6,8,10$ and $12 \%)$ were prepared either by diluting or adding lactose (Difco) to the medium.

Effect of potassium phosphate. Different concentrations of $\mathrm{KH}_{2} \mathrm{PO}_{4}: \mathrm{K}_{2} \mathrm{HPO}_{4}$ mixtures were added to permeate medium at a ratio concentration of $0.5: 0.5$, $0.5: 1.0$ and $0.5: 1.5 \mathrm{~g} / \mathrm{l}$, respectively, compared with the control.

Effect of initial $\mathbf{p H}$. The influence of different initial $\mathrm{pH}$ values was examined. The $\mathrm{pH}$ values were adjusted at 5.0, 5.5, 6.0, 6.5, 7.0, 7.5, 8.0 and 8.5 using either $\mathrm{NaOH}$ or $1 \mathrm{~N} \mathrm{HCl}$.

Effect of nitrogen source. Various nitrogen sources were used separately at an equivalent concentration of $0.33 \mathrm{~g} \mathrm{~N} / 1$ media (Murad, 1998). The nitrogen sources included 4 inorganic forms $\left[\left(\mathrm{NH}_{4}\right)_{2} \mathrm{PO}_{4},\left(\mathrm{NH}_{4}\right)_{2} \mathrm{SO}_{4}\right.$, $\mathrm{NH}_{4} \mathrm{Cl}$ and $\mathrm{NaNO}_{3}$ ] and 4 organic sources (yeast extract, beef extract, peptone and tryptone).

Effect of nitrogen concentration. The optimum nitrogen source chosen was tested for its most suitable concentration ranging from 0.165 to $0.990 \mathrm{~g} \mathrm{~N} / \mathrm{l}$.

Effect of incubation temperature. The effect of incubation temperature was studied. The incubation temperatures ranged from 25 to $45^{\circ} \mathrm{C}$ (with $5^{\circ} \mathrm{C}$ increments), except for $37^{\circ} \mathrm{C}$ (the control), using electric chamber incubators.

Enzyme activity assay. $\beta$-galactosidase was assayed according to the method of Lederberg (1950) as described by Sanchez and Hardisson (1979). The method was strictly applied, except for the centrifugation speed which was used for separation of the bacterial cells and the sonicated cell debris at $4^{\circ} \mathrm{C}$. The centrifugal speeds used were modified to 8,000 $\mathrm{rpm} / 10 \mathrm{~min}$ and $15,000 \mathrm{rpm} / 20 \mathrm{~min}$, respectively using Sigma 2K15 centrifuge.

Statistical analysis. The significances of the results were determined by the analysis of variance (ANOVA) evaluated by Duncan's multiple range tests (at 0.05), using COSTAT software, product of Cohort software Inc., Berkley, California, (Duncan, 1955).

\section{Results and Discussion}

Production of $\beta$-galactosidase by selected LAB strains. As shown in Fig. 1, $\beta$-galactosidase production showed no significant differences between the 7 tested strains, ranging from 9.3 to $10.4 \mathrm{U} / \mathrm{ml}$ under the given experimental conditions. According to the obtained results, S. thermophilus and L.reuteri (representing lactococci and lactobacilli, respectively) were chosen on the basis of the best mean $\beta$-galactosidase activity of 10.01 and $10.44 \mathrm{U} / \mathrm{ml}$, respectively for further studies on permeate-based medium.

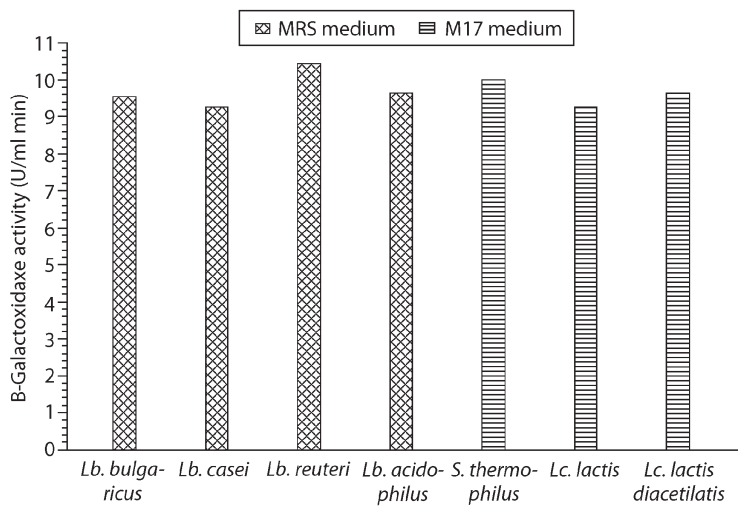

Fig 1. $\beta$-galactosidase production by LAB strains M17 and MRS media expressed as enzyme activity $(\mathrm{U} / \mathrm{ml})$ 


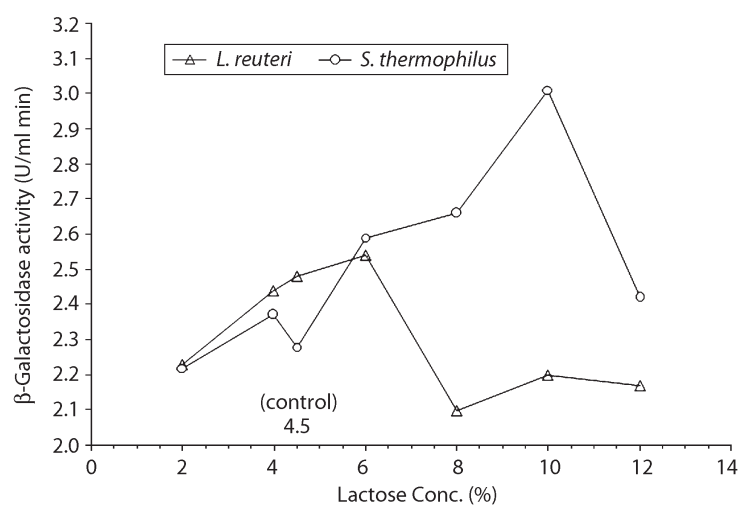

Fig 2. Effect of lactose concentration in permeate-based medium on the production of $\beta$-galactosidase.

Effect of lactose concentration. The data shown in Fig. 2 indicate that the production of $\beta$-galactosidase by L. reuteri and $S$. thermophilus strains increased with the increasing of lactose concentration (up to 6\%), reaching 2.54 and $2.59 \mathrm{U} / \mathrm{ml}$, respectively. Further increasing lactose concentration up to $10 \%$ decreased the L. reuteri enzyme production dramatically, while it increased the S. thermophilus enzyme production $(3.01 \mathrm{U} / \mathrm{ml})$. Hasan and Durr (1974) stated that lactose induced the synthesis of $\beta$-galactosidase.

As a fact, the amounts of carbon source in the medium may affect the expression of $\beta$-galactosidase by microorganisms (Fiedurek and Szczodrak, 1994; Inchaurrondo et al., 1998). The $\beta$-galactosidase activity increased as the concentration of lactose in the medium was increased up to $4.0 \%$. Further increasing the lactose content resulted in the reduction of $\beta$-galactosidase activity. A similar phenomenon was observed by Fiedurek and Szczodrak (1994) who investigated the biosynthesis of $\beta$-galactosidase by Kluyveromyces fragilis.

Inchaurrondo et al. (1998) clarified that the decreased $\beta$-galactosidase activity in the medium containing $5 \%$ or more lactose might be attributed to the increased concentration of internally released glucose which represses the biosynthesis of $\beta$-galactosidase by the test organism. Furthermore, it was demonstrated that $4 \%$ lactose was sufficient to induce the highest expression of $\beta$-galactosidase under the tested conditions.

This gives an indication about the efficiency of $S$. thermophilus to consume higher concentrations of lactose $(10 \%)$ than L. reuteri (6\%), indicated by the highest production of $\beta$-galactosidase. Besides, the upper limit of lactose concentration that the two strains can produce $\beta$-galactosidase efficiently couldn't be exceeded due to the accumulation of glucose by-products intracellularly, as discussed before.

Effect of potassium phosphate. The data shown in Fig. 3 illustrate the effect of potassium phosphate

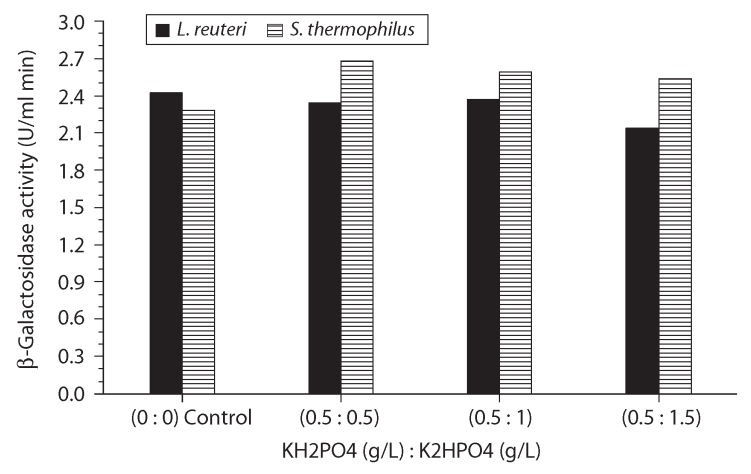

Fig 3. Effect of $\mathrm{KH}_{2} \mathrm{PO}_{4}: \mathrm{K}_{2} \mathrm{HPO}_{4}$ ratio (g/l) in permeate-based medium on the production of $\beta$-galactosidase.

(acidic and alkaline form) ratio on the $\beta$-galactosidase production by both strains. In case of $L$. reuteri there was no significant difference in $\beta$-galactosidase production magnitude for the control and the phosphate buffer treatments $\left(\mathrm{KH}_{2} \mathrm{PO}_{4}: \mathrm{K}_{2} \mathrm{HPO}_{4}, \mathrm{~g} / \mathrm{L}\right)$ at ratios 0.5:0.5 and 0.5:1.0 $(2.38 \mathrm{U} / \mathrm{ml}$, in average $)$. Increasing the alkaline phosphate form of potassium decreased the production level significantly at the ratio of $0.5: 1.5$. Apparently, there is no need to add potassium phosphate buffer because the control gave similar level of $\beta$-galactosidase production, but there is always a great need for the buffer to capture any possible excess in organic acid by-product (lactic acid), specially when the permeate sources are varied.

The production of $\beta$-galactosidase by $S$. thermophilus showed a significant difference between the control test and the whole added phosphate buffer forms ratios. At 0.5:1.0 and 0.5:1.5 ratios $\left(\mathrm{KH}_{2} \mathrm{PO}_{4}: \mathrm{K}_{2} \mathrm{HPO}_{4}\right.$, $\mathrm{g} / \mathrm{L})$ the $\beta$-galactosidase production mean increased by $12 \%$ compared with the control, but at $0.5: 0.5$ ratio the increase of $\beta$-galactosidase production was $17.5 \%$ $(2.68 \mathrm{U} / \mathrm{ml})$, proving its dominancy over the control and other treatments.

These data agree with what Ramana Rao and Dutta (1977) discussed in their work on S. thermophilus production for $\beta$-galactosidase that was obviously stimulated by the monobasic phosphate buffer form more than di- and tri-basic forms, while in the case of $K$. fragilis maximum $\beta$-galactosidase production was achieved by addition of $\mathrm{KH}_{2} \mathrm{PO}_{4}: \mathrm{K}_{2} \mathrm{HPO}_{4}$ buffer at a ratio of 1:3, as stated by Fiedurek and Szczodrak later (1994). Murad (1998) tested the $\beta$-galactosidase production level from L. bulgaricus using different $\mathrm{KH}_{2} \mathrm{PO}_{4}: \mathrm{K}_{2} \mathrm{HPO}_{4}$ buffer ratios at 1:2 and 1:3 and found that at the latter ratio the organism produced maximum $\beta$-galactosidase than at the former. Hsu et al. (2005) found that the best buffer ratio at which the Bifidobacterium produced maximum $\beta$-galactosidase was 1:3 $\left(\mathrm{KH}_{2} \mathrm{PO}_{4}: \mathrm{K}_{2} \mathrm{HPO}_{4}\right)$. 
Effect of initial $\mathrm{pH}$. The obtained data showed no effect of various initial $\mathrm{pH}$ values on $L$. reuteri production of $\beta$-galactosidase, except that there was an obvious decline in the enzyme production at the alkaline border beginning at $\mathrm{pH} 8$ and above. This proved the capability of $L$.reuteri to produce $\beta$-galactosidase at maximum level $(3.21 \mathrm{U} / \mathrm{ml}$, in average) through a wide range of initial $\mathrm{pH}$ (5.0 to 7.5). Maximum $\beta$-galactosidase production by $S$. thermophilus was obtained at $\mathrm{pH} 6.5$ $(2.77 \mathrm{U} / \mathrm{ml})$. The experimental results revealed that the increase in the enzyme production was gradually increased at $\mathrm{pH} 5$ up to 6.5 , followed by significant decrease in the production at $\mathrm{pH} 7$ up to 8.5.

The effect of the initial $\mathrm{pH}$ of the medium on enzyme production by $S$. thermophilus was studied over a $\mathrm{pH}$ range of 4.0 to 9.0 by Ramana Rao and Dutta (1977) and they reported that maximum enzyme production was observed between $\mathrm{pH} 6.5$ and 7.5. Sridhar and Dutta (1991) worked on the production of $\beta$-galactosidase from Streptococcus cremoris on whey. They reported that the optimum $\mathrm{pH}$ was between 6.5 and 7. The results presented by Murad (1998) showed that the highest enzyme production by L.bulgaricus was obtained at $\mathrm{pH}$ 5, while, Hsu et al. (2005) reported the optimum initial $\mathrm{pH}$ for $\beta$-galactosidase production by Bifidobacterium sp. to be 6.5. It is obvious that there is a great similarity in the effect of optimum initial $\mathrm{pH}(6.5)$ on the production of $\beta$-galactosidase by both strains (L. reuteri and S. thermophilus) and those reported previously by Ramana Rao and Dutta (1977), Sridhar and Dutta (1991) and Hsu et al. (2005).

The effect of nitrogen source. The observed results revealed that among the 8 nitrogen sources tested, the ammonium phosphate serving as a source for both nitrogen and phosphate, was found to be the best for maximum production of $\beta$-galactosidase by $L$. reuteri $(5.74 \mathrm{U} / \mathrm{ml})$ and $S$. thermophilus $(6.83 \mathrm{U} / \mathrm{ml})$. L. reuteri managed to use both organic and inorganic sources efficiently compared with the control, while, S. thermophilus preferred the simple nitrogen form (i.e. inorganic) more than the complex ones (i.e. organic).

This agreed with what was reported by Murad (1998), namely that the highest production of $\beta$-galactosidase by L. bulgaricus was obtained using $\left(\mathrm{NH}_{4}\right)_{2} \mathrm{HPO}_{4}$. Also, he mentioned that no activity was detected in the presence of $\left(\mathrm{NH}_{4}\right)_{2} \mathrm{SO}_{4}$. This fact was confirmed previously by Selim and EL-Diwany (1985) and Fiedurek and Szczodrak (1994) who reported that some salts such as $\left(\mathrm{NH}_{4}\right)_{2} \mathrm{SO}_{4}$ showed an inhibitory effect on $\beta$-galactosidase production by $K$. fragilis.

On the contrary, Ramana Rao and Dutta (1977) found that the best nitrogen source for the production of $\beta$-galactosidase by $S$. thermophilus was protease peptone, followed by ammonium sulphate, and they did not use any phosphate form of nitrogen.

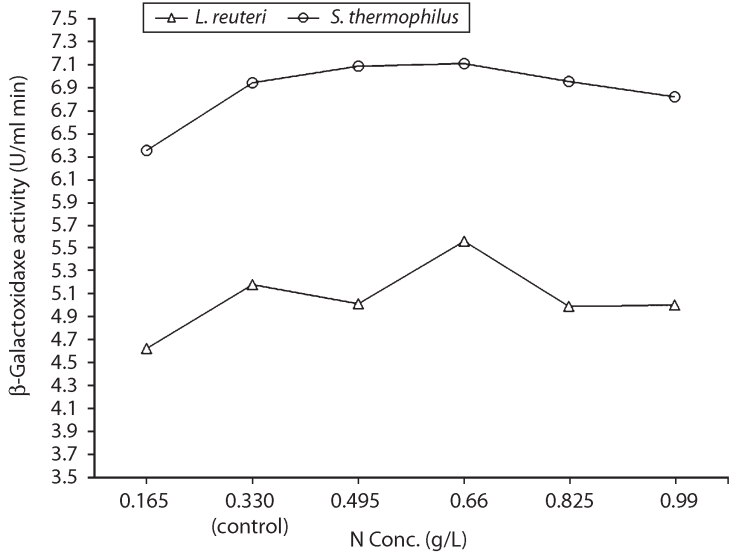

Fig 4. Effect of supplemented nitrogen concentration in permeatebased medium on the production of $\beta$-galactosidase.

These findings about the importance of nitrogen source were mentioned by Ramana Rao and Dutta (1977) and Shaikh et al. (1997), who found that nitrogen sources may affect the microbial biosynthesis of $\beta$-galactosidase.

Effect of nitrogen concentration. The preferred nitrogen source type (ammonium phosphate) chosen for both strains from the previous experiment was tested for its best concentration as shown in figure 4 . It is clear that $S$. thermophilus production of $\beta$-galactosidase was much higher than L. reuteri over all the ammonium phosphate concentrations tested.

Both strains showed the same trend in response to nitrogen concentration. The $\beta$-galactosidase production significantly increased as the nitrogen concentration increased; until it reached its best level when nitrogen concentration was twice $(0.66 \mathrm{~g} \mathrm{~N} / \mathrm{L})$ that of the control $(0.33 \mathrm{~g} \mathrm{~N} / \mathrm{L})$, as L. reuteri yielded $5.56 \mathrm{U} / \mathrm{ml}$ and $S$. thermophilus gave $7.11 \mathrm{U} / \mathrm{ml}$, then declined when it reached triple that of the control.

This trend agreed with the findings of Hsu et al. (2005) in their work on Bifidobacteria. The activity of $\beta$-galactosidase increased upon increasing the nitrogen source concentration but further increasing resulted in a sharp reduction in the activity of $\beta$-galactosidase and a reduced final population of the test organism.

Murad (1998) found that the concentration of $\left(\mathrm{NH}_{4}\right)_{2} \mathrm{HPO}_{4}$ in the growth medium of L.bulgaricus exhibited a profound effect on the production of $\beta$-galactosidase, as the highest activity was obtained using $0.4 \%$. While in case of L. reuteri and S. thermophilus, the the highest $\beta$-galactosidase activity was obtained using $0.3 \%$ only.

It is worth mentioning that Jokar and Karbassi (2009) maximized $\beta$-galactosidase production by Lactobacillus delbruekii when grown in permeate based medium enriched with a combination of yeast extract, whey 


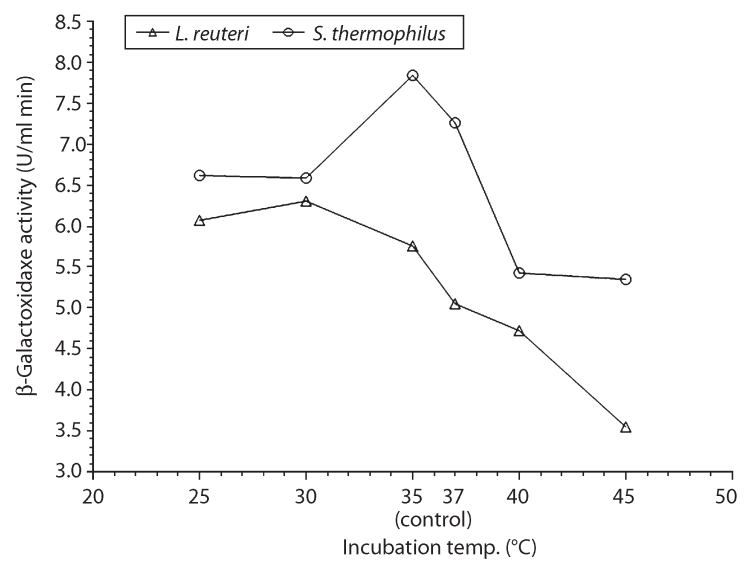

Fig 5. Effect of incubation temperature on production of $\beta$-galactosidase.

powder and wheat steep liquor as organic nitrogen sources to reach $4.924 \mathrm{U} / \mathrm{ml}$, less than that obtained in the current study (5.56 and $7.11 \mathrm{U} / \mathrm{ml}$ ) using only ammonium phosphate as an inorganic source.

Effect of incubation temperature. $L$. reuteri strain produced maximum $\beta$-galactosidase $(6.31 \mathrm{U} / \mathrm{ml})$ at $30^{\circ} \mathrm{C}$ followed by a significant decline in enzyme production with further increase in the incubation temperature (Fig. 5). The same trend in the production of $\beta$-galactosidase by $S$. thermophilus strain was observed with its maximum enzyme production $(7.85 \mathrm{U} / \mathrm{ml})$ at $35^{\circ} \mathrm{C}$.

Hsu et al., (2005) stated that the activity of $\beta$-galactosidase produced by Bifidobacteria increased as the cultivation temperature increased from $22^{\circ} \mathrm{C}$ to $37^{\circ} \mathrm{C}$. Further increases in the cultivation temperature led to a reduction of enzyme production accompanied by a reduction in the final viable population. These observations agree with those of Fiedurek and Szczodrak (1994) as well as Smith et al. (1985), which demonstrated that the highest $\beta$-galactosidase production by B. longum was obtained at $37^{\circ} \mathrm{C}$.

It could be concluded that the permeate $(4.5 \%$ lactose) as an industrial waste can be used efficiently in the production of $\beta$-galactosidase by either L. reuteri or S. thermophilus strains (6.31 and $7.85 \mathrm{U} / \mathrm{ml}$, respectively) when grown at initial $\mathrm{pH} 6.5$, if optimized by adding $\mathrm{KH}_{2} \mathrm{PO}_{4}: \mathrm{K}_{2} \mathrm{HPO}_{4}$, at ratio of 0.5:0.5 g/L and ammonium phosphate at $0.66 \mathrm{~g} \mathrm{~N} / \mathrm{L}$ as nitrogen source, with an incubation temperature of $30^{\circ} \mathrm{C}$ and $35^{\circ} \mathrm{C}$, respectively.

\section{Literature}

Agrawal S. and S.M. Dutta. 1989. Microbial $\beta$-galactosidase: production, properties and industrial applications. Indian Journal of Dairy Science 42: 251-262.
Duncan D. B. 1955. Multiple ranges and multiple F-Tests. Biometrics 11: 1-24.

Fiedurek J. and J. Szczodrak. 1994. Selection of strain, culture conditions and extraction procedures for optimum production of $\beta$-galactosidase from Kluyveromyces fragilis. Acta Microbiol. Pol. 43: 57-65.

Fu J. and Y. Tseng. 1990. Construction of lactose-utilizing Xanthomonas campestris and production of xanthan gum from whey, Appl. Environ. Microbiol. 56: 919-923.

Hasan N. and I.F. Durr. 1974. Induction of $\beta$-Galactosidase in Lactobacillus plantarum. Journal of Bacteriol. 120: 66-73.

Herreros M.A., J.M. Fresno, M.J. Gonzalez Prieto and M.E. Tornadijo. 2003. Technological characterization of lactic acid bacteria isolated from Armada cheese (a Spanish goats' milk cheese). International Dairy Journal 13: 469-479.

Hsu C.A., R.C. Yu and C.C. Chou. 2005. Production of $\beta$-galactosidase by Bifidobacteria as influenced by various culture conditions. International Journal of Food Microbiology 104: 197-206.

Huang Y. and S. Yang. 1998. Acetate production from whey lactose using co-immobilized cells of homolactic and homoacetic bacteria in a fibrous-bed bioreactor. Biotechnol. Bioeng. 60: 498-507.

Inchaurrondo V.A., M.V. Flores and C.E. Voget. 1998. Growth and $\beta$-galactosidase synthesis in aerobic chemostat cultures of Kluyveromyces lactis. J. Ind. Microbiol. Biotech. 20: 291- 298.

Jokar A. and A. Karbassi. 2009. Determination of proper conditions for the production of crude beta-galactosidase using Lactobacillus delbrueckii ssp. bulgaricus. J. Agric. Sci. Technol. 11: 301-308

Lederberg J. 1950. The beta-D-galactosidase of Escherichia coli, strain K-12. J. Bacteriol. 60: 381-392.

Marwaha S.S. and J.F. Kennedy. 1988. Review: Whey pollution problem and potential utilization. Int. J. Food Sci. Technol. 23: 323-336.

Mawson A.J. 1994. Bioconversions for whey utilization and waste abatement. Bioresource Technol. 47: 195-203.

Murad H.A. 1998. Utilization of ultrafiltration permeate for production of $\beta$-galactosidase from Lactobacillus bulgaricus. Milchwissenchaft 53: 273-276.

Novalin S., W. Neuhaus and K.D. Kulbe. 2005. A new innovative process to produce lactose-reduced skim milk. J. Biotechnol. 119: 212-218.

Petzelbauer I., B. Nidetzky, D. Haltrich and K.D. Kulbe. 1999. Development of an ultra high temperature process for the enzymatic hydrolysis of lactose. I. The properties of two thermostable $\beta$-glycosidases. Biotechnology and Bioengineering 64: 322-332.

Ramana Rao M.V. and S.M. Dutta. 1977. Production of BetaGalactosidase from Streptococcus thermophilus Grown in Whey. Appl. and Environ. Microbiol. 34: 185-188.

Rings E.H.H.M., E.H. Van Beers, S.D. Krasinski, M. Verliave, R.K. Montgomery, R.J. Grand, J. Dekker and H.A. Büller. 1994. Lactase: origin, gene expression, localization and function. Nutrition Research 14: 775-797.

Sanchez J. and C. Hardisson. 1979. Induction of $\beta$-galactosidase in Streptomyces violaceus. Can. J. Microbiol. 25: 833-840.

Selim M.H. and A.J. El-Diwany. 1985. Chem. Mikrobiol. Technol. Lebensm. 9: 81-86. Cited in: Murad, H.A. 1998. Utilization of ultrafiltration permeate for production of $\beta$-galactosidase from Lactobacillus bulgaricus. Milchwissenchaft 53: 273-276.

Shaikh S.A., J.M. Khire and M.I. Khan. 1997. Production of $\beta$-galactosidase from thermophilic fungus Rhizomucor sp. J. Ind. Microbiol. Biotech. 19: 239-245.

Smith P.K., R.I. Krohn, G.T. Hermanson, A.K. Mallia, F.H. Gartner, M.D. Provenzano, E.K. Fujimoto, N.M. Goeke, B.J. Olson and D.C. Klenk. 1985. Measurement of protein using bicinchoninic acid. Anal. Biochem. 150: 76-85. ) 
Sridhar N. and S.M. Dutta. 1991. Ind. J. Dairy Sci. 44: 283. Cited in: Murad, H.A. 1998. Utilization of ultrafiltration-permeate for production of $\beta$-galactosidase from Lactobacillus bulgaricus. Milchwissenchaft 53: $273-276$

Stiles M. and W.H. Holzapfel. 1997. Lactic acid bacteria of foods and their current taxonomy. International Journal of Food Microbiology 36: 1-29.

Vasiljevic T. and P. Jelen. 2001. Production of $\beta$-galactosidase for lactose hydrolysis in milk and dairy products using thermophilic lactic acid bacteria. Innovative Food Science \& Emerging Technologies 2: 75-85.

Zadow J.G. 1993. Economic considerations related to the production of lactose and lactose by-products. Lactose hydrolysis, IDF Bulletin 289. IDF, Brussels, pp. 10-15. Cited in: T. Vasiljevic and P. Jelen. 2001. Production of $\beta$-galactosidase for lactose hydrolysis in milk and dairy products using thermophilic lactic acid bacteria. Innovative Food Science \& Emerging Technologies 2: 75-85. 